\title{
Çocuk - Kültür ve \\ Medeniyet İzleğinde: \\ Prof. Dr. Medaim Yanık ile Söyleşi
}

\author{
SÖYLESEN: AYSE KAYA KETECI
}

Özet

Ruh sağlığı ve hastalıkları alanında uzman olan Prof. Dr. Medaim Yanık, uzmanlık tezini çocukluk çağı travmatik yaşantıları ve dissosiyatif bozukluklar alanında yapmıştır. Halihazırda İbni Haldun Üniversitesi Psikoloji Bölümünde çalışmalarını sürdürmektedir. Temel araştırma alanı çocukluk çağı travmalarının erişkinlerde uzun vadeli etkileridir. Ayrıca çift terapistidir. Eş / evlilik terapileri bağlamında "Eş Seçimi Eğitim Programı" ve "Evlilikleri Geliştirme Eğitim Programı" isimli özel programlar geliştirmiştir. Prof. Dr. Medaim Yanık tıp alanındaki bilgisini pratik alanda başarıyla uygulamış; eş seçimi, evlilik, ebeveynlik ve çocuk ilişkisine dair kapsamlı araştırmalar yürüterek önemli eserler vermiştir. Bu anlamda mesleğini ahlaken icra etmesi çalışmalarına özel bir konum kazandırmıştır. Görüşmedeki amaç bu önemli tecrübeyi çocuk ve aile ilişkisi minvalinde, kültür ve medeniyet izleğinde açmaktır. Toplumsal değişim sürecinde ailenin yaşadığı dönüşümü ele alarak aileye kendisini koruyabileceği temel düzeyde bir yol haritası sunmaktadır.

Anahtar kelimeler: Çocuk, aile, travma, kültürel aktarım, medeniyet.

Ayşe Kaya Keteci: Çocukların büyüdüğü aile ortamının onları hayat boyu etkilediği biliniyor. İyi bir aile ortamında büyümeyen çocuklar yetişkin olduklarında ne gibi eksiklikler yaşar ve bunlar nasıl telafi edilebilir? 
Prof. Dr. Medaim Yanık: Çocukluğun nasıl geçtiği meselesi, bir insan tekini hayatı boyunca etkileyen bir mesele. Olumlu, pozitif, geliştirici bir çocukluk dönemi kişinin hayatını ömür boyu olumlu olarak etkilerken; travmatik bir çocukluk dönemi kişinin hayatını ömür boyu olumsuz etkileme eğilimindedir. Bu olumlu ve olumsuz etkileme birkaç yönden olur ve beyni etkileme kapasitesine sahiptir. İnsan beyni çocuklukta, değişim ve gelişim dönemindedir. O dönemde yaşanan şeyler zihni şekillendiriyor. Şekillenmekte olan bir zihne, direkt müdahalede bulunuyor. Mesela meşhur çocukluk çağı travmalarının beyne etkisi çalışmalarında ACE Çalışması (Advers Childhood Experiences studies) olarak bilinen çocukluk travmaları arttıkça, kişinin yaşam boyu hem fiziksel hem ruhsal sağlığında belirgin bir risk faktörü. Bu risk, travma sayısı arttığı zaman artıyor. Bunun yöntemi nasıl oluyor? Aslında birkaç yolla oluyor. Beyni direkt yapısal olarak etkiliyor. Beynin düşünme mekanizmalarını, beynin impulsivite dediğimiz hızlı gelen davranışları kontrol etme becerileri veya karar alma süreçlerini veya korkuyu, duygusal süreçlerindeki biyolojik mekanizmalarda anatomik değişiklik yaparak etkiliyor. İkincisi ise, bedenin stres hormonu düzenlemesini, strese karşı cevabını olumsuz etkileyerek yapıyor. Bunun sonucunda çocukluk çağı travması yaşamış ve özellikle de bunu yoğun yaşamış kişilerde; diyelim ki obezite, aşırı kilolu olma, kalp hastalıklarına yakalanma, hatta kanser olma, madde bağımlısı olma, depresyon geçirme, intihar etme riski gibi her alanda bariz risk yükselmesine sebep oluyor. $\mathrm{Bu}$ artık psikiyatri içinde, psikoloji geleneği içinde, tıp geleneği içinde belgelenmiş bir durum. Bundan pek bir şüphemiz yok. Tersi de geçerlidir. Çünkü çocukluk çağı döneminde olumlu yaşantılar yaşamış olmak beyinde pozitif anı peak experiences yani yoğun duygusal pozitif anı dediğimiz özel bir yaşantılar, deneyim dediğimiz şeyler yaşam boyu hafızada olağandan fazla ve farklı kayıt haline geliyor. Benim "Çocuk Yetiştirirken Travmatik Yanlışlar, Geliştiren Doğrular” diye bir kitabım var. Bu kitabımda klinik ortamda gördüğümüz travmatik yaşantıların psikolojiyi nasıl etkilediğine dair örnekler görüyoruz. Bu kitabın ikinci bölümündeyse 750 kişiye çocukluklarında yaşadıkları, video gibi hatırladıkları pozitif anıları sorduk. Orada da enteresan bir şey var. Normalde bir hafıza, otobiyografik hafıza dediğimiz bir şekilde çalışıyor. Olayları öykü şeklinde anlatıyorsunuz. Ama bir yaşantı eğer travmatik olursa veya pozitif özel bir yaşantı olursa bunlar video gibi kayıt oluyor. Ve zihin sistemine, zihni istediğiniz zaman o ana gidercesine; daha canlı duygusuyla beraber, zaman ve mekanla beraber çağırabilme potansiyeliniz oluyor. Ve o an ve anılar, bizim bugünkü ruh halimizi bariz etkiliyor. Yine çocukluk çağı travmaları eğer bir çocuğun zihnini bölebilecek dissosiyasyon yaparsa, bu sefer de zihnen sakatlanma dediğimiz bir hal oluşuyor. Mesela diyelim bir kişinin bacağının kırılması, 
onu hayat boyu etkileyebilirse, -iyileşmemişse eğer- tedavi edilmemiş, onarılmamış bir travmatik yaşantı da çocuğun zihninde bölünme yaratarak onda ömür boyu zihin bölünmesi dediğimiz dissosiyatif kimlik bozukluğu dediğimiz bir halin kalmasına neden oluyor. Bu bizim önemli bir ruh sağlığı sorunu diyebileceğimiz bir hal oluşturuyor. Özellikle özetle şunu diyebiliriz; kişinin bireysel ruh sağlığı, çocukluk çağının nasıl geçirildiği başka insanlarla ilişkileri, bedensel sağlığı, madde kullanıp kullanmaması açısından iki yönlü; pozitif ya da negatif yönlü olarak oldukça ilişkili.

Ayşe Kaya Keteci: Peki kendinde bu travmatik deneyimleri görüp yaşayan kişi bunu kendi kendine telafi edebilir mi yoksa muhakkak destek alması mı gerekir?

Prof. Dr. Medaim Yanık: Çalışmalar bize travmatik yaşantının şiddeti ve sıklığı, miktarı arttıkça sonuçlarının, ağırlığının da arttığını gösteriyor. Bir de tabi travmanın hangi konsept ve kontekste geliştiği önemli. Travma listelerini daha küçük ve incelikli hale getirirsek, birçok insan aslında çocukluk çağında bir şekilde bazı şeyleri yaşıyor. Ama daha büyük maddeler halinde söylersek; diyelim çocukluğunda fena halde dövülmüş olmak, tekrarlayıcı bir şekilde ortamda kalmış olmak veya cinsel bir tacize maruz kalmak veya sürekli kavga ortamının yaşandığı bir evde kalmak. Bunların şiddetleri yüksek olduğu için, sonuçları ağır olduğu için negatif bir sonuç üretme ihtimali de daha yüksek. Ama anne babanız makul ölçüde iyi geçiniyor. Ara sıra kavga ettiler ve siz o kavgaya şahit oldunuz. Bir saat sonra ya da bir gün sonra pozitif bir şekilde barıştılar. Çocuk, bir kavga ve barışma sürecini görüyor. Çocukla da ilgili toplam atmosfer pozitifse, bu bir negatif yaşantı olsa bile zihni bölebilecek, kalıcı olabilecek bir psikoloji oluşturmayabilir. Neden? Birincisi; burada düzeltici, onarıcı mekanizmalar var. Genel atmosfer pozitif, anne baba ilişkiyi onarmış, çocuk büyük bir şeyin içinde kalmamış. Bir de manzarayı şöyle bir tersten çevirelim: Çocuk her gün anne babanın kavgasını görüyor, evde kavga rutine binmiş durumda, evde boşanma lafları geçiyor. Diyelim ki anne, baba evden çekip gittiğinde arkasından "İnşallah bir daha bu eve gelmezsin!" diye dua (veya beddua) ediyor. Çocuk bunu görüyor. Çocuk başka bir odaya geçip "Allahım, annemin duasını kabul etme!" diyor. Çünkü çocuk, oradaki bağlamı anlamıyor. Belki o kişi gerçekten de dönüyor. Annenin söylediği de sahici bir şey değil, öfkeyle söylenmiş bir şey. Çünkü eşi gerçekten gitse arkasından belki de o anne ağlayacak. Bu böyle ama o çocuğun dünyasında, o büyük resimde

Çocuk ve Medeniyet 2021/1 sürekli kaldığı haliyle, çocuk zihni bunu negatif yorumlama eğiliminde, bir kere hassaslaşmış zaten. $O$ çocuk, orada, babasının gideceği ve bir daha dönmeyeceği, annesinin de bunu Allah'tan çok içten istediği şeklinde 
algılayabilir. Bakın burada konteks farklı, bu travmatik. Her evde sorun olur mu? Olur. Çocukları dünya cennetinde yetiştirmemiz gerekmez. Bazı şeylere de dayanıklı olması gerekir. Evin içinde olabilecek insani sorunlar ve bunların sonradan doğru dürüst ele alınarak çözülme süreci, çocukların problem çözme yeteneklerini bile artırabilir. Bu anlamda "Aman çocuğa bir şey olur!" diye suni bir ev atmosferi yaratmak gerekmez ama travmatik bir ev atmosferinin de birçok çalışma ve klinik gözlemde çocuğa kalıcı zarar verdiği de açık ve net.

Ayşe Kaya Keteci: Aile içi travmatik etkiler yaşamış birinin toplumsal katılımı nasıl olur?

Prof. Dr. Medaim Yanık: Benim mutlu evlilikler üzerine bir araştırmam var, aynı zamanda çift terapistiyim. Çocukluk çağı travmalarının erişkinlerde uzun vadeli etkilerini de çalışıyorum. İkinci uzmanlık alanım çift terapileri. Çift terapilerinde sorunları olan çiftleri görüyorum. Bir yandan da gerçeğin, bir tek bu yüzü olmadığını bildiğim için mutlu evlilik araştırması da yaptım. Hatta TRT Haber'de 13 program olarak yayınlanan 'Mutlu Evliliklerin İzinde' diye bir programım da vardı. Buradaki mantık şu: resmin diğer boyutunu görmek. Eş ilişkilerinin yıkıcı olabileceği kadar, oldukça olumlu olabileceğini görmek. Ortalamanın, çoğunluğun da bu ikisi arasında bir yerde olduğunu bilmek. İnsanların yetiştikleri ortamlar aile ilişkilerini nasıl etkiler? Bu sorunun cevabı şu: Aile içinde olumlu bir atmosferde büyümüş olmak, ilişkinin sevgi dolu olduğunu görmüş olmak, aile içinde iletişim halinde olmak, dayanışmayı görebilmek; kişinin kendi kurduğu ailesinde ve diğer insanlarla ilişkisinde böyle olma olasılığını artırır. İki, diyelim ki senaryo, çocuğun ailesinde sorunlar var. Çocuk, bu sorunların negatif etkilerini görüyor. Çocuk kalıcı izler almadan, zihni bölünmeden, ağır yaralanmadan buradan çıkabilmeyi başarmış. Ve böyle bir bilinçle ve bu çocuğun kendisinin de benzer bir aile ilişkisi kurma olasılığı yüksek. Bakın olasılık yükselir, mutlak son değil. Ama şöyle bir seçeneği de olabilir: "Ben çektim, kendi çocuklarıma çektirmeyeceğim." Mutlu evliliklerde böyle bir izlek gördük biz. Anne babaların hepsi mutlu değil. Bir kısmının anne babasının mutsuz evlilikleri var. Ve kişi diyor ki: "Ben mutsuz bir evliliğin nasıl olduğunu gördüm, kendi aileme bunu yaşatmayacağım." Onun için eş seçiminden eşle ilgili ilişkilere kadar çok özel bir hassasiyet göstererek evliliğini iyi tutmak için büyük bir çaba gösteriyor. Ama üçüncü senaryoda, eğer evde yaşananlar çocuğun zihnini bölecek seviyede ağır sonuçlar oluşturmuşsa çocuğun bu şeyden çıkıp kendi ailesiyle, toplumla olumlu ilişkiler kurması zor. Çünkü burada artık yaralanmış biri var. Bu kişinin iyi ilişsiler kurma şansından ziyade, o zihnin bölüklügünün diyelim 
ki öfkesini, korkusunu, güvensizliğini kendiyle beraber bütün ilişkilerine, ailesine, toplumsal yapıya da taşıyabileceğini düşünmemiz lazım. Yani üç tane büyük izlekten bahsediyoruz. İlişki pozitifse; çok büyük ihtimalle kendi pozitif taşıyacaktır. Ama yine de karşısındaki kişinin negatifiyle değişebilir. Hayat boyu devam eden bir süreç. İkincisi; aile ilişkileri negatifse, burada negatif olma olasılığı artabilir. Ama kişi pozitife çevirmeyi de başarabilir. Eğer aile ilişkileri çocuğa çok zarar verdiyse, bu üçüncü grup, çok büyük ihtimalle bütün aile ilişkilerine negatif olarak yansıyacaktır. Çünkü kişi "Aile içinde insanlara güvenilmez. Ancak kendini koruman gerekir. Bütün ilişkiler problemlidir. Yeryüzünde iyi şeyler olmaz." diye düşünebilir. Çocuk, o şiddetli travmatik ortamla mücadele edebilmek için her türlü stratejiyi kullanır. Her türlü strateji sonra birbirleriyle ayrışır, uçlara gider. Sonra bunu kendi hayatında uyguladığı için de o çoklu ruh hali, ilişkileri bir şekilde bozar. O yüzden bu senaryoda negativitenin devamı daha mümkündür.

Ayşe Kaya Keteci: Çocukların duygusal gelişimini ve sosyal hayatını desteklemek isteyen aileler, çocuklarını yetiştirirken nelere özen göstermelidir?

Prof. Dr. Medaim Yanık: Anne babalık yapma tarzının bir çocuğu, çocukları, toplumsal yapıyı ve insan gücümüzü etkilediğini net olarak biliyoruz. O yüzden Türkiye'nin stratejik planında insan gücünü artırmanın yollarından biri de nasıl dil bilen, teknolojileri kullanan insan sayısını artırmayı hedefliyor isek, ruhsal olarak sağlıklı, az travmatize olmuş -ya da hiç olmamış- sağlıklı yetenekler, gelişkin bireyler oluşturmak için çabalamaktır. Bu, toplum mühendisliğinin ötesinde bir şey. Buna ihtiyacımız var. Nasıl ki Türkiye'de kadına şiddeti engellemek ve azaltmak ile ilgili büyük bir stratejik planımız varsa, ki bu mümkün, ama zor ve uzun vadeli bir iş. Çocukları travmadan korumak, ruhsal ve fiziksel daha sağlıklı bir nesil yetişmesi için de bir takım müdahale programlarının stratejik planlamasını yapmak gerekir. Türkiye'deki akıl bu noktaya gelmiş mi emin değilim, ama böyle bir mesele gerekli. Bunun için de benim tezim; anne babalık öğrenilebilir, öğretilebilir. En azından bulundukları hal düzeltilebilir, iyileştirilebilir. Ben sürekli çocukluk çağı travması yaşamış kişilerin öykülerini dinliyorum. Bunların bir kısmı önlenebilir travma dediğimiz şeyler. Travmaların bir kısmı vahşi, kötü, zalim ancak adli yöntemlerle durdurulabilir insanlar üzerinden oluyor. Bunların bir eğitim programından ziyade, aynen kadına şiddeti engelleme/kadını korumada olduğu gibi adli yöntemlere ihtiyacı var. Bunların uygulanmaya devam etmesi ve güçlendirilmesi lazım. Ama önemli oranda travmatik 
yaşantı önlenebilir. Belki anne babaların farkındalığı artsa veya aileler desteklenmiş olsa veya ailenin becerileri artsa önlenebilir bir alan var burada. Bu önlenebilir olanın önlenmesi için işte müdahale programları lazım. Bu yüzden Türkiye'nin hızla toplumsal düzeyde yaygınlık kazanabilen kurumsallaşmış anne babalık eğitim programlarına ihtiyaç var. Türkiye bu anlamda çaba içinde mi? Bireysel düzeyde çaba içinde. Anne baba rollerinin önemini, dünyadaki fikirler Türkiye'ye yansıyor veya kendimiz bunu zaten fark ediyoruz. Küçük kurumlar düzeyinde, belediyeler düzeyinde böyle çabalar var. Fakat bu çabalar yeterince kurumsal değil. Eğitim müfredatları üstüne uzun süreli çalışılmış değil. Üçüncüsü ise, toplumsal katmanlara yaygınlaşmış değil. Belediyelerde genellikle seminerler şeklinde. Halbuki, bu işin üzerine çalışılmış, workshop haline getirilmiş, eğitim içerikleri beceri öğretmeye planlanmış, yapısal olarak kurumsallaştırılmış ve toplumsal katmanlara yayılabilir hale getirilmiş olması gerekir. Türkiye'nin en az bu şekilde yürüyen ondan fazla anne babalık eğitim programına ihtiyacı var. Bunların da sürekli toplumsal düzeyde yaygınlaşması lazım. Ben şu aralar tam da böyle bir proje üstünde çalışıyorum. Bu kitabın içeriğini biraz daha geliştirilmiş haliyle, yedi saatlik bir workshopa çevirmeye çalışıyoruz. Benim geliştirmek üzere olduğum bir ekiple beraber çalışıyoruz. Programın dört tane modülü var. Bu dediğim kriterleri yapmaya yönelik. Birinci modül; çocuğu travmadan korumak, travmatize etmemek, travmaya uğramışsa da hızlı bir şekilde onarmak. Çocukluk çağındaki kötü şeyleri engelleme. İkinci modül, çocuğun gelişebileceği, büyüyebileceği pozitif bir ilişkiler ağı, sosyal çevre, doğa veya hayvanlarla olan bir yaşam ortamı oluşturmak ki; burada doğal haliyle gelişebilsin. Şöyle düşünün; bir çiçek var. Birileri onun dalını koparmasın. İkinci olarak da güneşi, suyu bol olan bir yer olsun ki, kendi doğasıyla gelişsin çocuk. İlişkiler ağı olsun, çünkü yalnızlık yıkıcı bir şey. Çocuk evde, apartmanda kalmasın. Doğayı keşfedebilecek bir ortamda olsun. Kuzenleriyle, arkadaşlarıyla bir bağ kurabilsin ki keşfedebilerek gelişsin. Çok makul bir şey, birinde dalı koparmayı engelliyorsunuz. Diğerinde çocuğun doğal ihtiyacı olan şeyleri verip çocuğun kendi serpilmesine müsaade ediyorsunuz. Üçüncü şey, biraz da böyle bahçıvan tarzında müdahale gerekir: "Bu çocuk acaba hangi yeteneklere sahip?”, "Bu çocuk hangi spor, müzik alanında ilerleyebilir?", "Bu çocuğun karakter gelişimi nasıl olabilir, dinini, maneviyatını nasıl kazanabilir?", "Bu çocuğun akademik hayatında nasıl bir gelişme olabilir?” gibi çocuğun haline bakarak bu dört alanda gelişimi ile ilgili özel bir çaba gösteriyorsunuz. Bunun modellemesi bizim geleneğimizde şöyle

Çocuk ve Medeniyet 2021/1 var: Babasından şu eğitimi, dedesinden ve dayısından şu eğitimi, şu hocadan da şu eğitimi almış veya şu kişi onu keşfedip geliştirmiş. Modern versiyonlarıyla beraber düşünürsek böyle. Burada dalını kırmadık, yetişmesi 
için doğal hale bıraktık ama biraz da bahçıvanlık yapıyoruz. Bu çocukta ne var diye bakıp, onu travmatize etmeden, yarıştırmadan, zorlamadan ama onun birtakım araçlara sahip olması için, dili, becerisi olan alanların geliştirilmesi, dinini ve maneviyatını öğrenmesi, akademik gelişimi için erken dönemde çocuğun potansiyeline bakarak bunu nasıl geliştirebiliriz, anne babalara bu yeteneği vermek. Çünkü burada iki ihmal var: Çocuğu aşırı zorlarsanız travmaya dönüşüyor. Çocuğun potansiyeline bakıp o eğitim atmosferine aktiflik sağlamazsanız, ihmal oluyor. Çünkü ikincisinde çocuklarla arkadaş oluyor, oynuyor. Ama burada bir özel plan lazım çocuk için. İşte bunu doğru bir düzeyde yapmış olduk. Dördüncü modül, sonuçta çocuk yetiştirmede sıklıkla karşılaşılan bir dizi problem var. Mesela uyku problemleri olabilir. Geceyi gündüz, gündüzü gece yapmış olabilir. Yeme ile ilgili problemler olabilir. Yemek saatlerine uymama, sofra kurallarına uymama, aile ile birlikte yemek yememe gibi. Ekran sorunları olabilir. Erken ilişkiler olabilir. Bir dizi 20-30 tane başlık altında sayabileceğimiz, sık sorun dediğimiz bir şey var. Bunlara karşı ailelerin meseleyi ele alma biçimlerini geliştirmemiz lazım. Bu sık sorunlar karşısında ailelere bir düşünme, meseleye yaklaşma biçimi, birtakım beceriler öğretmemiz lazım ki buralarda hata yapmasınlar ve gelişimlerine katkı sağlasınlar. Çünkü kim olursanız olun, bu problemlerin büyük kısmıyla kendi çocuğunuz karşılaşacaktır. Siz bunları nasıl ele alacaksınız? Anne babalara biraz bunu öğretmeliyiz. Muhtemelen yakın zamanda bu çalışmayı bitireceğiz. Çünküi çerçeveyi tamamladık, içeriğini dolduruyoruz. Bunun bir kitapçığının olması, bir slayt setinin olması, bir workshop materyali haline dönmesi, eğitimcilerin eğitilmesi, belli aralıklarla Türkiye'de devam etmesi ve İslam dünyasında da yaygınlaştırılması gibi bir hedefimiz var. İşte bu çocuk yetiştirmeyle ilgili ailelere vereceğimiz bir katkı. Bu yapılan anne babalık denen doğal bir şeye karşı modern bir müdahale gibi düşünülüp entelektüel dille eleştirilebilir mi? Eleştirilebilir. Doğrudur. Burada anne babaların uzman bağımlısı haline getirilmemesi ve spontanitelerini kaybetmemeleri, yeni bir okul tarzına dönüşmemesi gerekiyor. Bunlar kabul, ama bu risklerin olmadığı bir modelle işler yürütülebilir. Çünkü aşırı entelektüelize edilmiş yaklaşım hareketsizliğe, eylemsizliğe, sorunu görmemeye yol açıyor. Bu türden çabaları, kişisel gelişim hareketini aşağılamaya dönüşerek yapılmasını Türkiye'ye veya insana büyük zarar verdiği kanaatindeyim ben. Bu kişisel gelişim hareketini aşağılayan entelektüel yaklaşımın vurgu yaptığı bazı noktalarda haklı olmakla birlikte büyük bir gerçekliği unuttuğu kanaatindeyim ben. Yani suyunun suyu olan sıradan şeyleri pazarlama taktiği ile kişilerin ön alması meselesiyle, sahiden geliştirilmiş ve emek verilmiş anlayışın toplumsal düzeyde yayılması arasında ciddi farklar olduğu kanaatindeyim.

Çocuk - Kültür ve Medeniyet İzleğinde:

Prof. Dr. Medaim Yanık ile Söyleşi 
Şimdi mesela diyelim ki Avustralya'da 25 yıldır yapılan Triple P (Olumlu Anne Babalık Eğitim Programı) diye bir program var. 25 dile çevrilmiş. Bu türden programlar Avustralya'da anne babaların \%10-15-20'sine ulaşmıştır. Türkiye'de böyle bir programın ulaşmış olma oranı \%0.1'in altında. Şu anda nasıl kendi arabamızı yapamadık, yapmaya çalışıyoruz ya, bunun gibi kendi ana babalık eğitimimizi yapıp toplumsal düzeye yaymalıyız. Bence Türkiye'nin kendi arabasını yapması gibi bir strateji veya kadına karşı şiddetle mücadele etme gibi benzer bir parçası olmak zorunda.

Bunu şundan söylüyorum. 'Mutlu Evliliklerin 7 Özelliği ve Mutlu Evlilik Atölyesi' diye bir atölye hazırladım. Programı aşağı yukarı iki yılda tamamladım. Bu program İngilizceye de çevrildi. Amerika'daki Müslüman topluluklara uygulanıyor. Türkiye'de yaklaşık 10. veya 11. kez yaptık. Bir günlük bir program. Çiftler, eşler yan yana oturuyor. Karı koca katılmazsa, programa almıyorum. Aralarında mahremiyet korunuyor. Kendi aralarında, kendileri için çalışıyorlar. Topluluğa kendi sırlarını vermiyorlar. $\mathrm{O}$ anlamda güvenliklerinin de sağlandığı bir program ama bu programın toplumsal düzeye yayılmasıyla ilgili ciddi zorluk var. Proje ekonomik olarak batık, ben destekliyorum. Erkekleri, eşleriyle beraber oturup kendi evlilikleri için çalışmaya pek ikna edemiyoruz. Bu türden bir program batıda oldukça yaygın. Neredeyse 40-50 yıllık bir geleneği var. Bunların Türkiye toplumu içinde kabul görmesi için çabaya ve zamana ihtiyacımız var. Türkiye toplumundaki alışkanlık ya vaaz kültürü ya da seminer kültürü. Diyelim ki beni insanlar bir yere davet ediyor. Ne istiyorsunuz? 40-50 kadını bir yere toplayacaklar, ben onlara konuşma yapacağım. Bunların hiçbirine gitmiyorum artık. Neden, çünkü gidiyorsunuz, sadece kadınlara konuşuyorsunuz. Kadınların bilgi düzeyleri artıyor. Gidip eşine yardımcı mı oluyor, kavga mı ediyor? Bunu anlamak zor oluyor. İkinci yönü ise, biri anlatıyor diğerleri dinliyor. Pasif, kendilerine özgü bir şey yapmış olmuyor. Bunları küçümsemek istemem ama bu bir eğitim programı değil benim için. Benim gözümde eğitim programı olabilmesi için, iki eşin birlikte katılması gerekiyor. Çocuk yetiştirme programında ise anne babadan biri olabilir. Orada belki daha esnek olabilirim. Anne babanın beraber olup, üzerine iyi çalışılmış bir programda kendi çocuklarıyla ilgili ya da kendi evlilikleri ile ilgili özel düşündüğü, ilerisi için planlar yaptığı; ilerisi için geliştirme planı, normali artırma planı. Bunlar tedavi planı değil. Bu türden şeyler bir terapi değil. Normali geliştirme, iyileştirme, koruma dediğimiz şeyler. Yoksa terapi yerine geçmez. O yüzden bütün topluma yayılabilir. Bu türden konferans-

Çocuk ve Medeniyet 2021/1 seminer-vaaz formatı yerine -onların yeri olabilir, yıkıcı davranmak istemem ama- bizim bu türden bir formatı yerleştirmemiz lazım. Bununla ilgili çabaların çok uzun yolu var. Kimse şöyle sanmasın: Ben anne babalar için 
güzel bir eğitim programı hazırladım, anne babalar buna gelecek. Hiç öyle olmuyor. Programınızın kurumsallaşması gerekiyor, kitlelere ulaşması gerekiyor, mesajın kampanya şekline dönüştürülmesi gerekiyor, bunun ulaşılabilir ekonomik mekanlarının olması gerekiyor. Hatta bu eğitimi veren kişilerin kurumsal düzeyde güvenlerinin çok olması ya da toplum düzeyinde tanınır ve kabul edilebilir hale gelmesi gerekiyor. $O$ yüzden bu tür çabaların çoğu yarım kalıyor. Yani küçük işletmeler gibi düşünün. 100 tanesi açılıyor, 95'i eleniyor. 5 tanesi kalıyor. Bizim bu anlamda gelişmiş, oturmuş bir tane programımız yok. Yani benim kriterlerimde Türkiye'nin şu anda anne babalık ya da evlilik güçlendirme programı yok. Çabalar var, Aile Bakanlığının da çabaları var ama benim saydığım kriterlerde benim programım da dahil olmak üzere, onu karşılayabilen herhangi bir şey şu anda yok. Ama olmaz mi, olur. Bal gibi olur. Bu alanda mücadele etmek lazım.

Ayşe Kaya Keteci: Aile içi problemlerin temel sebepleri nelerdir? Çocukların zarar görmemesi için neler yapılmalıdır?

Prof. Dr. Medaim Yanık: Burada odağımız çocuk olacak. Çünkü eşler arası problemlerin çok sayıda sebebi var. Çocukla ilgili boyutunda, anne babalar çocuk yetiştirirken nerede hata yapıyor? Birincisi ya fark etmeden travmatize ediyorlar ya da travmadan koruyamıyorlar. Yahut çocuğun yetiştiği ortam, bir çocuğun yetişmesi için uygun bir atmosfer değil. Çok fazla ev eksenli, dar bir alan, az sayıda insan ilişkisi, çok yapılandırılmış eğitim kurumlarında geçen zamanlar yani bizzat sürecin kendisinde problem var. Veya anne baba çocuğu anlama ile ilgili, çocuğu yetiştirmeyle ilgili üzerine düşünülmüş bir program ve anlayışa sahip değil. Veya zor problemlerle nasıl baş edileceği konusunda bilgiye sahip değil. Sorunlar buradan kaynaklanıyor. Toplumsal halk sağlığı düzeyinde en temel birkaç şey söyleyeyim. Çocuğun yalnız kalmış olması çok önemli. Çocuğun kendi başına vakit geçirmesi çok hoş bir şey, kendi oyuncaklarıyla oynayabilmesi, kendi başına kalabilmesi çok güzel. Ama yalnız çocuk dediğimiz; görülmez çocuk. Bazen bizim hastalarımız kendilerini şöyle ifade ederler. Sosyoloji okumamışlardır ama kendi yaşamlarından kavramsallaştırırlar: "Ben evde görülmezdim, ben sanki yokmuşum gibi. Ben kendi başımaydım, kimse bana dikkat etmezdi. Sadece karnım doyurulur, üstüm başım giydirilirdi. Ben kendi başıma yaşardım.” derler. Çocuk kendi başına çok fazla yalnız kalırsa aşırı bir hayal dünyası geliştiriyor. Hayal dünyası iyi bir şey gibi duruyor ama hayal dünyanızda çocuklar yaratıp sonra da bu çocuklardan

Çocuk ve Medeniyet 2021/1 ibaret bir dünya, yapay zekayla kalıcı kişilik bölünmelerine sebep oluyor. İkinci en önemli sorun, anne babanın şiddetli geçimsizliği çocukları çok kötü etkiliyor. Şu anda bizim zihin bölünmesi dediğimiz şeyin en sık 
sebebi cinsel taciz değil. Cinsel tacizin travmatik olduğu herkes tarafindan kabul edilen bir şey. Anne babanın çocuğun hissedebileceği şekilde açık ve ağır şekilde geçimsizliği hali, diyelim ev içindeki şiddet, uygun olmayan psikolojik atmosfer çocuk için en yaralayıcı şey. Çocuklar, bunun altından çok zor çıkıyorlar. Üçüncü şey, çocuğu anne babanın büyütmede esas rolden vazgeçmesi. Bu ne demek? Bir yandan şöyle bir şey istiyoruz; bir çocuğu sadece bir anne baba büyütmesin. Bu çocuğun teyzeleri, dayıları, amcaları, dedeleri olsun, ilişkiler ağı içinde olsun, kuzenleri olsun, mahallede büyüsün, bir yandan bunu istiyoruz. Ama esas büyüteni anne babası olsun. Anne babası varken diğerlerine alan açıyoruz. Ama çocuğu anne babanın büyütmemesi sorun. Mesela Almanya'ya işçi gidersiniz, çocuğu anneanneye bırakırsınız, bu travmatiktir. Ya da anne baba çok çalışıyor, çocuğu anneanneye bırakıyor, hafta sonları görmeye geliyorsa bu travmatiktir. Bu anne babanın, anne babalık görevini başkasına devretmesi anlamına gelir. Bu kabul edilebilir bir şey değildir. Bir çocuk, bir anneye babaya aittir. Temel anne babalık, bir başkasına özel şartlar yoksa, ölüm yoksa, sakatlık yoksa, ağır hastalık yoksa; orada hastalıkta bile içinde olması lazım yani, çocuğun bir başkasına verilmesi, esas sorumluluğun alınmaması, sanki emaneten kendisindeymiş gibi olması büyük problem. Bağlanma gerçekleşmiyor. Çocuk sanki istenmediğini düşünüyor. Bağı kuramıyor anne babasıyla. Annesi annesi mi nenesi mi; babası dedesi mi babası mı karıştırıyor. $\mathrm{Bu}$ düzeydeki bir şeyi istemiyoruz. Bir anne babanın çocuğu tek başına, ufacık bir apartman katında başkalarından kopuk yetiştirmesi problemli. Aileden kimse yok, anne çocuğu tek başına büyütüyor. Annenin hayatı mahvoluyor. Bir hayat alanı kalmıyor. Çocuk tek bir ilişki ağı içinde büyüyor. Bunun eleştirisi çok doğru bir eleştiri. Bunun tamamlanmış hali ne? Akrabalarla, kuzenlerle, arkadaşlarla, mahalleyle bağlantı kurarak çocuğu büyütmek. Ama anne babanın anne babalıktan vazgeçtiği, çocuğun başkası tarafından büyütüldüğü, anne babanın esas olmadığı model doğru kabul edilemez.

Ayşe Kaya Keteci: 'Mutlu Evliliklerin 7 Özelliği’ kitabınızda evlilikte ortak yaşamdan kaynaklanan sorunlar hususunda bir bölüm var. Burada mutlu bir evlilik için 'boş zamanların nasıl değerlendirileceği' konusunda bir uzlaşma sağlanması gerektiğinden bahsediyorsunuz. Benim zaman zaman sorduğum bir soru var. Medya araçlarına yönelmek, özellikle birlikte TV izlemek ortak bir boş zaman aktivitesi midir? Aile ve medya araçları-TV ilişkisi nasıl düzenlenmelidir?

Çocuk ve Medeniyet 2021/1
Prof. Dr. Medaim Yanık: Aslında belki internette bulunabilir, ben bir öğrencime tez yaptırdım. 'Ailede Sosyal Medya Kullanım Kılavuzu' diye. Yani “Ailede sosyal medyayı nasıl kullanacağız?” sorusuna odaklanıldı. 
Çalışma biraz köşede kaldı, önerileri bakımından toplumsal katmanlara yayılamadı. Bir şey yapıyorsunuz. Onu kitlelere ulaştıracak mekanizmaları kuramadığınız zaman olan emek kenarda kalıyor. Programın temel önerilerinden biri ekranın kontrol edilmesi şeklinde. Neden? Ekrandaki olan şey çok hızlı, çok fazla mesaj veriyor. O yüzden insan zihninde, özellikle çocuğun zihninde çok fazla dopamin salgılamasına sebep olarak bir nevi bağımlılık yapıyor. Ekrandaki çizgi film ya da Youtube dünyasındaki şeyler veya sosyal medyanın kendisi çok fazla uyarı vererek zihni bir şekilde çok hızlı dopamin yoluyla bağımlı hale getiriyor. Fastfood gibi. Üç şey birbirine çok benzer. Pornografi izlemek, fastfood yemek yemek ve çocukların internette uzun kalması. Bunların üçü de çok hızlı bir şekilde beyinde dopamin salgılatıp, bu aktiviteye kişiyi bağımlı hale getirir. Bağımlı olduğunuzda dozajı artırmanız gerekir. Bağımlılığın özelliği budur. Dozajını artırarak sizi çeker. Daha fazlasını istersiniz. Aslında sizin doğal yapınızı bozar, çünkü insan zihni aralıklı zevke ayarlanmıştır. Sürekli dopamin zevkine giderseniz, bir zamandan sonra sizi bozar. Daha fazla bağımlılığa sebep olur. Kontrolsüz, saatler süren sosyal medya kullanımı haline bir düzen getirmemiz lazım. Oldukça zor bir meseleyle karşı karşıyayız. Tekil olarak soruyu şöyle soruyorsanız; bir ailenin aktiviteleri arasında beraber film seyretmek varsa, bu eşler arası bir şey, çocukla da olabilir, evet bu bir aktivitedir. Çünkü aile beraber bir şey yapıyor, bunu da beraber yapıyor. Baba-çocuk ya da aile aktivitesi ya da eşler aktivitesi de olabilir. Bunun pozitif bir eylem olarak kabul edilmesi gerekir. Ama klasik haliyle herkesin elinde cep telefonu, herkesin elinde tablet, herkes kendi dünyasında bir ekran karşısında ise; evin rutini bozulacak şekildeyse, herkes ayrı bir dünyada yaşayacak hale geldiyse, bu ana aktivite haline gelmişse, uzun zaman alıyorsa, burada açıkça bir problem var. Çünkü beraber yapılan bir aktivite olarak kabul edilemez. Bir aile beraber çok şey yapıyor, belli bir saatte de oturup beraber film izliyorsa bu pozitif bir aktivite. Ama aileler, işte herkes kendi dünyasında, herkesin kendi ekranının başında olması problemli. Sürekli ekran başında olmak, sürekli yemek yemek gibi bir şey. Bunlar aynı şey. Aileyi bozuyor. O yüzden bizim kılavuzda ailelere en önemli tavsiyelerimizden birisi, akşam yemeği vakti ailenin bir araya gelme zamanıdır, bir ritüeldir. Ritüel sırasında telefonlar dahil olmak üzere bir kenara bırakılmalıdır. Bizim için iki şey; ailenin akşam yemeğinde birlikte olması ve akşamleyin çay-meyve faslı ailenin bir araya geldiği bir ritüeldir. Herkesin kendi başına zaman aralıklarıyla aile ritüelleri arasında denge

Çocuk ve Medeniyet 2021/1 öneriyoruz. Ama mutlaka ailelerin bir araya geldiği, ekranın olmadığı, onların bir nevi bilinçli olarak da uzaklaştığı özelleştirilmiş aile zamanları, eş zamanları, anne-çocuk, baba-çocuk zamanları oluşturulmalı.

Çocuk - Kültür ve Medeniyet İzleğinde:

Prof. Dr. Medaim Yanık ile Söyleşi 
Ayşe Kaya Keteci: Günümüzdeki COVID-19 salgınında yeni bir durum söz konusu oldu. Çocuklar olabildiğince ev koşullarında aileleriyle zaman geçiriyor. Hem bedensel hareketlilik hem de sosyal anlamda sınırlı şartlar içinde hayatlarına devam ediyorlar. Bu durum çocuk gelişimini nasıl etkileyecektir?

Prof. Dr. Medaim Yanık: Bu süreç insanlık için hayırlı bir süreç değil. Birçok aile ve kişi bu koşullardan olumsuz etkilendi. Örneğin COVID döneminde toplum olarak kilo ortalamamız arttı. Daha obez bir topluma döndük. Araştırmalar onu gösterdi. Neden, çünkü daha az fiziksel aktivite yapıyoruz. Salgının getirdiği hayat biçimi, doğal hayat biçimimizi bozdu. Biz sadece eve ait değiliz. Ev bizim mekanımız, üssümüz ama biz aynı zamanda mahalleye, çarşıya, iş yerine; çocuksak parka, okula aitiz. Çoklu alanda, mekanda zaman geçirmemiz gerekir. Çoklu aktivite ile uğraşmamız gerekiyor. Bunun için de fiziksel aktivitenin zihinsel aktivite ile beraber olması gerekiyor. COVID bize mekanı daralttı. Aktiviteleri sınırladı, hareketliliğimizi azalttı. Tamam, buna mecburuz. Bir takım uzman kılavuz önerileri oluşturduk. Mesela benim internete yazarsanız 'Aileler İçin COVID Döneminde 10 Öneri’ diye grafikleştirilmiş bir öneri paketimi görebilirsiniz. Orada ailelere bu dönemde ne yapacaklarını önerdik. Mesela tipik önerilerimizden biri, sonradan gelişti o kültür, ev içinde mutlaka ailece fiziksel egzersiz yapın. Aileyle beraber vakit geçirme. Çünkü kendi kulağımla da birkaç kez duydum. Bazı kadınlar COVID sürecinden çok memnun. Eşini evde neredeyse hiç görmeyen, eşi sürekli dışarılarda olan, hızlı bir hayat yaşayan kişiler; hayatın yavaşlaması, eşin evde olması, birbirlerine daha fazla vakit ayırabilme yakınlığı artırdı. Şöyle bir şey oldu: COVID ortalama düzeni bozdu. Benim tezim şu, bazı aile ilişkilerini iyileştirdi. Zor zamanlar böyle yapar. Çünkü dayanışma ve birbirine vakit ayırma arttı. Hayat yavaşladı, daha fazla konuşabilecekler. Ama çoğunlukla negatif arttı. Çünkü zaten geçimi zor olan insanlar dar alanda oldu. Biraz sağlık problemleri ve ekonomik problemler oluştu. Çocukların eğitimiyle ilgili süreçler bozuldu. Toplamda ağırlıklı olanın aileye zarar verdiği şeklinde. Bizim bütün çabamız ailenin bu zararını azaltmak yönünde. $O$ yüzden klasik öneriler; çocukla da COVİDi konuşun, anlamlansın. İkincisi de ailede birine bir şey olması durumunda, yasını yaşama ile ilgili süreçlerin konuşulması gerekiyor çocukla. Hastalık ve ölümle ilgili meseleler. Ailenin beraber COVIDe karşı önlemler konusunda uzlaşması gerekiyor. Bu dönemde aile rutinleri oluşturmak önemli. Bir de aile aktivitesi ile bireysel alan dengesini sağlamak da çok önemli. Çünkü eskiden eşler, çocuklar bir şekilde kendi özel alanlarını oluşturabiliyorlardı. Çok kapandığınız zaman kendi özel alanınızı oluşturmak zor. Çünkü modern evler, kutu evler. Bu dönemde nasıl bir evde 
oturduğumuz o kadar önem kazandı ki. Çünkü yaşam alanı oluşturması lazım; bahçesi var mı, balkonu var mı, çıkabileceğiniz güvenli alanı var mı? Birçok aile maalesef buna sahip değil. O yüzden de bireysel alanlar kalmadı. Bizim bireysel alan ve zamanla, aileyle olan zaman arasında bir nevi dengeyi bulmamız lazım. Özel alanı da yok etmememiz lazım. COVID biraz eşler ve çocuklar için özel mekanı ve zamanı da yok etti. Bunun da dengesinin sağlanması lazım.

Ayşe Kaya Keteci: Bu aşamada sorularımı aile ve kültürel aktarım başlığı altından seçiyorum. Ailelerin toplum yapısı üzerindeki etkisinden bahsedersek günümüzde ailelerin çocuklarına toplumsal kültürü ne kadar aktarabildiklerini söyleyebiliriz?

Prof. Dr. Medaim Yanık: Bence hala bir numaralı rol ailede. Ama bu rol çözülüyor. Ben hala bir numaralı belirleyicinin aile olduğunu düşünüyorum. Ama bir oran varsa, ailenin etkisi azalıyor. Daha çekirdek aileye iniyor, geniş ailenin etkisi giderek azalıyor. Çekirdek aile hala yüksek olmakla beraber, dış dünyanın etkisi, sosyal medya araçları giderek büyüyor. Artık ailelerin şöyle açık bir derdi var: çocuklarını kendi kimlikleriyle uyumlu bir halde tutabilme mücadelesi var. Bu hep vardı. Her zaman aileler kendi kimliklerini bir sonraki nesle aktarmak isterler. Doğal hal, böyle de olur. Sosyal psikoloji bize bunu gösteriyor. Diyelim ki, bir çocuğun anne babası Galatasaraylı ise, o çocuk \%80 ihtimalle Galatasaraylı olur. Bir kız çocuğunun annesi örtülüyse, çocuk büyük ihtimalle örtülü olur; annesi açık ise büyük ihtimalle açı olur. Sosyal değerlerin yaşam yoluyla, doğal haliyle aktarılması sosyal psikolojinin temel şeyi. Ailelerin buna hakkı da var. Çocuk aileye aittir. Çocuk insan teki, kendisidir ama aileyle beraber büyüyor. Devlete, başka gruplara değil çocuk aileye aittir. Ama giderek daha fazla sayıda aile kendi çocuğuna kendi kimliklerini geçirme ile ilgili endişe içinde. Niye? Çünkü ailenin kendi kültürel kodlarını çocuğa geçirebilme gücünde azalma, dış dünyanın belirleyici olma gücünde artma oluyor. $\mathrm{Bu}$ oran dengesiz hale geliyor. Eskiden çok fazla aile lehineydi. Büyük aile vardı. Toplumsal bir değer, yakın ilişkilerden oluşmuş bir kültür vardı. Şimdi dünyanın her tarafından oluşan akımlar, sosyal kodlar, sosyal medya, değişen hızlı dünya aracılığıyla ailenin etki gücünü baskılayarak yeni bir etki gücü oluşturuyor. O yüzden birçok aile; çocuklarının inançlarının kendine benzer olup olmaması, çocuklarının giyimlerinin kendileri için en azından kabul edilebilir düzeyde olup olmaması, çocukların gündelik hayat akışlarının inandıkları şekilde olup olmasıyla ilgili başları büyük dertte. $\mathrm{O}$ yüzden de anne babalık görevi, her zamankinden biraz daha emek gerektiren bir iş. Çocuğun kimlik kazanma sürecine, o kimlikle gelişme sürecine eşlik 
etmek gibi bir görevimiz var. Bu görevi başkasına da devredemeyiz. Başka kurumlara devretmenin zorluklarını gördük. Yani çocuğun dinini öğrenmesi için filan yere giderse -başka kurumlara da ihtiyacımız var olabilir amabunların süreçlerini de denetlemesi gerekiyor. Batıda çocuk yetiştirmede homeschool denen, çocuğun eğitiminin anne babanın kontrolünde evde verilmesi yaklaşımları var. Çocuğun hem karakter olarak hem akademik olarak yetiştirilmesinde esas rolün aile içinde kalması gerektiğiyle ilgili bir akım var. Yani insanlar şunu görüyor: Daha büyük dış dünyada bir heykeltıraşın bir çamura şekil vermesi gibi çocuğunuza şekil veriyor, bunda sizin etkinizin kalmadığını fark ediyorsunuz. Anne babaların bununla ilgili daha bilinçli bir çaba içinde olması gerekiyor. Anne baba aktif olmazsa sizin tarlayı başkaları ekiyor. O yüzden de anne babalık giderek daha fazla donanım gerektiren bir işe dönüşüyor. Maalesef modern dünya bize yük üstüne yük veriyor. Ama hayatta daha önemli neyiniz var? O yüzden en önemli şeye yatırımı başka zamanlardan kısıp buraya yapmanız lazım. Deyimiyle; "Ben çocuğumu sokakta bulmadım." Başkasının tarlamı sürmesine, şekillendirmesine karşı mücadele edeceğim. Bu açlığını gidermek gibi bir çaba, çocuğun kimlikleşme sürecine rehberlik etmek anne babanın görevidir. Bunu başka kurum ve kişilere mutlak tamamı ile devredemeyiz. Modern dünya kurumların güvenirliliğinin problem olduğu bir yer. Bunun sorumluluğunun toplumsal denetlenemediği sonuçları oluyor. "Ne yapayım ben? Ekmek parası peşindeyim. Çocuğu da şunlara teslim edeyim. Onlar da çocuğu dine uygun yetiştirsin." dediğinizde, iş kontrol edilemeyen noktalara gidiyor. Çünkü hiçbir kurum bu düzeyde güvenirliği hak etmiyor. Herhangi bir okul, okul dışı bir kurum veya devlet veya başka bir şey. O yüzden anne babaların kendi çocuklarına rehberlik etme yetkinliği peşinde olması gerekir. $\mathrm{Bu}$ vazgeçilmez bir problem.

Ayşe Kaya Keteci: Post modern topluma geçişler yaşadığımız bir süreçteyiz. Yani yerleşik otoriteler sarsılırken yeni iktidar kaynakları ve biçimleri ortaya çıkıyor. Bundan etkilenen en önemli kurum da aile. Ailenin ahlaki ve doğru bilginin kaynağı olma hususunda eski konumunun zayıfladığını görüyorum. Yeni nesil üzerinde bu anlamda otoritesi de daha zayıf. Bir anlamda kendi çocuğumuzu yetiştiremiyoruz. Bu durumun aile ve uzun vadede toplum üzerindeki etkileri nasıl olacak? Yani akış nereye doğru?

Prof. Dr. Medaim Yanık: Bütün dünyada ailede bir değişim var. Ailedeki değişimde gerçek düzeyde olan şu: Bir, ailedeki üye sayısında azalma oluyor.

Çocuk ve Medeniyet 2021/1
Geniş aileden çekirdek aileye, çekirdek ailenin çözülme sürecine geçiyoruz. Hane halkında yaşayan kişi sayısı giderek azalıyor. Aynı trend artık Türkiye'de de oluyor. İki, evlenme yaşları büyüyor. Diyelim ki bir İskandinav 
ülkesinde bir kadının evlenme yaşı 33, erkeğin de 35-37 civarına yükselmiş durumda, Türkiye'de son elli yılda kadının ilk evlenme yaşı neredeyse beş yaş falan arttı. Şu anda kadınlar için ortalama evlenme yaşı Türkiye'de 24,525 arası, erkekler için 27. Bu trendin giderek artacağını biliyoruz. Türkiye geriden Batı trendini, modernleşme sürecini takip eden bir ülke. Üçüncü, çocuk sayısındaki azalma. Doğurganlık trendinin bütün dünya ile beraber Türkiye'de de azaldığını biliyoruz. Yani bunu engelleme çalışmaları çok kolay bir iş gibi görünmüyor. Türkiye'de nüfus, doğum oranlarında düşme trendi devam edecek. Yalnız yaşama oranları artacak, artıyor. Beşinci şey, boşanma trendleri artıyor. Türkiye'de son 70 yılın istatistiklerine baktığınızda dramatik şeklinde değil ama basamak basamak boşanma süreçleri artıyor. Şimdi bu modernleşme sürecinin aileye olan etkileri, bütün dünyada da böyle oldu. Türkiye de bu trendin içinde, o yolda gidiyor. Bu büyük bir değişim demektir. Ailelerin, bu toplumsal yapıdaki değişiminin endişe edilecek tarafları olduğu kanaatindeyim. Bu bir değişim, tamam. Bazı kişiler, ne yapalım böyle oluyor diyebilir ama bu trendlerin nereye kadar gideceğini, bir insan gücü, toplumsal yaşamı etkileyen bir unsur olduğu kanaatindeyim. Yani buralara karşı etkin araçlarla iyileştirme çabaları yapmak anlamlı. Bence boşanmanın bir optimal hali var. Fazlası da azı da zarar. Ucuzdan boşanma zarar, gereken boşanmayı engellemek de zarar. Bu işin doğru bir optimal yeri var. Mesela buralarda toplumsal kılavuzlar oluşması gerekiyor. Yerli yerindelik dediğimiz bir halin oluşması gerekir. Buralarda toplumsal mühendislik biraz sert olur ama akıllı sosyal politikalar gerekir.

Bir toplum için insan gücü en kıymetli şey. Sizin vakfınızın da medeniyet ifadesi, medeniyeti oluşturan en temel şey aslında insan gücü. İnsan gücü, bir ülkenin, bir topluluğun, bir medeniyetin en önemli unsurudur. İnsan niteliğimizi artırmak, korumakla ilgili bir çaba rasyonel ve gerekli. Bunun etkili mücadele araçları hakkında, neyin işe yaradığı, neyin yaramadığı konusunda biraz daha gelişkin fikirlere ihtiyacımız var.

Ayşe Kaya Keteci: Bu soru bir önceki sorunun devamı niteliğinde. Ailenin bireyler üstündeki eski etkinliğinin zayıflaması bağlamında, bu durum aile ve kültürel aktarım hususunda ne gibi zorluklara yol açacak?

Prof. Dr. Medaim Yanık: Medeniyet dediğimiz şey, bir öze bağlı olarak yeni eklemeler yaparak değişimi gösterir. Medeniyet çünkü şöyle bir kavram; süreklilik gösteriyor. Kesinti göstermiyor. Ne demek? Mesela İslam, medeniyetinin parçasıysa diyelim ki kutsal dinler, Allah'ın dinleri dediğimiz şey, bunun son formu İslam dini. Bunun oluşturduğu medeniyet anlayışı var. Medeniyet dediğimiz şeyin sürekliliği olur. Bir şey özüne bağlı olarak yeni şartlarda gelişerek, zenginleşerek, derinleşerek yürümek anlamına 
da gelir. Çünkü medeniyetlerin böyle salınımı vardır. Dümdüz bir şey değildir, yükselişi inişi vardır. Daralması, genişlemesi, zenginleşmesi, fakirleşmesi vardır. Ama medeniyet dediğimizde birtakım değerler var. Bu değerlerin sürekliliğiyle birlikte bizim istediğimiz şey derinliğinin artması, zenginleşmesi, yeni araçlara ulaşması ama özünü kaybetmeden devam etmesi. Değer aktarımı, tutum aktarımı, inanç aktarımı, yaşam biçimi aktarımı en temel mesele. Bu değer aktarımı diyelim ki; her zaman bütün medeniyetler bunu aile, okul, eğitim kurumları üstünden yapar. Cemaatler, dini organizasyonlar ya da kurumlar üstünden yapar. Bizim bunların her birinde iyi bir hale gelmemiz lazım. Ama şu gerçeklikteki en önemli şey aile gibi görünüyor. Hala en sağlam şey, en sağlam kale, tutulacak yer, en değer verilecek yer hala aile. Medeniyet sürecinin işleyebileceği, aktarılabileceği yer aile gibi görünüyor. Ama ailenin kendi yapısını koruyarak bir sonraki kuşaklara değer aktarımı risk altında. Modernizasyonun riski altında. $\mathrm{Bu}$ sebeple aileyi güçlendirebilme mücadelesi içinde olmamız lazım.

Son on yıldır, kendime bu kalan ahir ömrümde topluma hayırlı ne yapabilirim diye soruyorum. Ben bir doktorum, hasta tedavi ediyorum. Bireyleri tedavi etmenin ötesine geçmek istiyorum. Benim şu andaki yaşam projem; aile ile ilgili dört eğitim programını, atölye şeklinde geliştirip, kurumsallaştırıp, bunları sadece Türkiye içinde değil İslam dünyasında da, ulaşabilirsek insanlığın diğer kısmına da uygulamak.

Ayşe Kaya Keteci: Bir çocuk büyürken bir mahalleye ihtiyacı olduğu söylenir. Günümüzde çocuklar büyürken akraba ve komşu ilişkilerinin önemi hakkında neler söyleyebilirsiniz?

Prof. Dr. Medaim Yanık: Anne babalık atölyemde anne babalara vermeye çalıştığım mesajlardan biri tam da bu. Bir bitkinin ışığa, suya ihtiyacı gibi çocuğun bir sosyal çevreye ve ilişkiler ağına ihtiyacı var. Anne babanın kendileriyle ve çocukla birlikte oluşan kapalı bir dünyaya övgü yapmaları yanlış. Bir nevi nenelerinden, dedelerinden uzaklaştırıp onların kendi iç dünyalarında yaşaması, çocuğa zarar veren bir şey. Çocuğun ilişkiler ağına, deneyimler, anılar kazanmasına ihtiyacı var. Mesela benim kitabın yeşil tarafına bakın; dedelerle, nenelerle, teyzelerle, halalarla ilgili çok sayıda pozitif anı var. Çocuğun bir mahalle ortamında yaşamış olmasının çok büyük katkısı var. Modern çocuk şöyle bir çocuk, her anı gözetilmiş bir çocuk, keşfetmesi biraz az bir çocuk. Keşfetmede en ileri tetkikler bile bir okul ortamındaki, duvar arasındaki keşfetme. Halbuki çocuğun doğayı, hayvanları biraz gözetim altında olmaksızın keşfederek var olmayı, doğal ortamda insan ilişkilerinde beceri kazanmayı, doğa ve hayvanlarla bağ kurabilecek, keşfedebilecek deneyimler yaşaması, bir nevi evden çıkıp mahallede zaman 
geçirip geri dönebilmesi. Hedefimiz bu. Burada çok ikili bir şey var, onu dengelememiz gerekiyor. Bir yandan travmadan korurken, diğer taraftan dış dünyada deneyim kazanmasını sağlamalıyız. Bu sebeple benim mesajım şu; aşırı korumanın kendisi de travma. Dünya o kadar da güvensiz değil. Binlerce çocuk bu şekilde bir araya gelip başına bir şey gelmeden eve dönüyor. Bir nevi eğitimle çocukla iyi bir bağ kurarak, makro gözetimleri yaparak çocuğun ilişkiler ağı içinde ya da mahalle ortamında kalmasını sağlamak. Ama bunları derken bu öyle bir yere kadar gidiyor ki, bir şehrin mahalle örgütlenmesine kadar geliyor. Yani çocuğunuzun sokağa çıkıp gelebileceği bir mahalle atmosferinin olup olmaması. Çocuk sokağa çıktığı anda trafiğe giriyor. İşte sosyal çevrenin dizaynı bu anlamda çok önemli. Çocuklar için yaşam alanlarının oluşturulması, şehrin bir mahalle dizaynı şeklinde olması çocuk yetiştirmenin çok önemli bir parçası.

Ayşe Kaya Keteci: Aslında son soru anlattıklarınızın özü niteliğinde, aile ve çocuk ilişkisinin kültür ve medeniyete katkısını nasıl değerlendirirsiniz?

Prof. Dr. Medaim Yanık: Evet, bir medeniyet iddiasına inananlardan biriyim. Medeniyetimizin ayakta kalmayı başarmasına rağmen zor bir dönemde olduğunu biliyoruz. Birkaç yüzyıldır en büyük derdimiz o. Ama medeniyetler yedi canlıdır derler. Düştügü yerden kalkıp yeniden yükselebilir. Buradaki en önemli şey kültürün yeniden inşası, değerlerin yeniden inşası ve aktarımı ile ilgili yeni yollar bulabilmek. Burada da en önemli şey insan yatırımı. İnsan yatırımındaki en önemli şey, çocuğa olan yatırım. Çocuğa olan yatırımda olan temel şey de aile olduğu kanaatindeyim. Yani bir nevi medeniyet güçlendirilmesi ailenin güçlendirilmesiyle çok ilişkili bir şey. O yüzden diyelim ki, uzay çalışmalarına başlayan bir Türkiye'nin aileye emek vermesi, aile-çocuk yetiştirme ile ilgili onlarca programı da beraberinde geliştirmesi gerekiyor. Yani bir nevi aileleri güçlendirmenin ASELSAN'ını kurmamız gerekiyor. ASELSAN'ın projeleri var ve teknoloji üretiyor. Benzer şekilde aileyi güçlendirmeye yönelik desteklenmiş yüzlerce kuruma, müdahale programlarına ihtiyacımız var. Aileyle ilgili iş yapan ASELSAN'lara ihtiyacımız var. Bu bir kültürel ve medeniyet dirilmesini, ailenin güçlenmesini sağlayabilir. Aile, sözle güçlenmiyor. Koronavirüs için aşı geliştirdik değil mi? Aileyi de iyileştirme, daha zor bir şeydir o aşı geliştirmekten. Uzaya araç göndermekten de zordur. O, paranız varsa teknik bir grup mühendisle yapılabilir. Ama aileyi iyileştirme ile ilgili sosyal şeyler daha zor şeylerdir. Ama bu anlamda Türkiye'nin insan gücüne yatırım yapma ile ilgili bir akla, planlamaya, 2021/1 yüzlerce birime ihtiyacı olduğu kanaatindeyim. Bunun zamanı, şu anda bunu yapmamız gerekiyor. 
Ayşe Kaya Keteci: Değerli vaktinizi bize ayırdınız. Anlattıklarınız, gündelik hayatından itibaren türlü araçlarla, açık ve gizli müdahalelerle etki altına alınmaya çalışılan modern insan bilincine güncel bir farkındalık kazandırıyor. Tüm bu maruziyete rağmen bir 'karşı koyma-bozma' motivasyonu sağlıyor. Bu çizgide ilerleyebilmek için yenilenen bir motivasyona ihtiyacımız var. Teşekkür ederim.

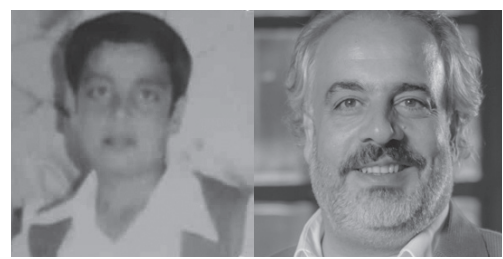

Medaim Yanık

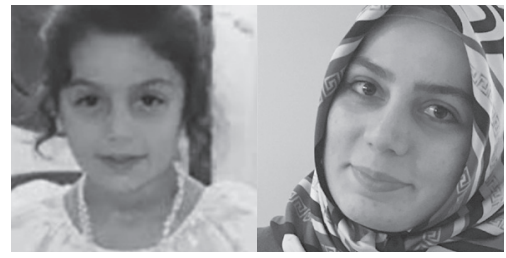

Ayse Kaya Keteci 